\title{
Controls on Gosaikunda Lake Chemistry within Langtang National Park in High Himalaya, Nepal
}

\author{
Maya P. Bhatt ${ }^{1,2^{*}}$, Seema Bhatt ${ }^{3}$, Birgit Gaye ${ }^{1}$ \\ ${ }^{1}$ Institute for the Biogeochemistry and Marine Chemistry, Klima Campus-University of Hamburg, \\ Hamburg, Germany \\ ${ }^{2}$ Asian Institute of Technology and Management, Khumaltar, Lalitpur, Nepal \\ ${ }^{3}$ School of Environmental Science and Management, Pokhara University, Kathmandu, Nepal \\ Email: "bhatt.maya@yahoo.com
}

Received 9 May 2014; revised 3 June 2014; accepted 28 June 2014

Copyright (C) 2014 by authors and Scientific Research Publishing Inc.

This work is licensed under the Creative Commons Attribution International License (CC BY).

http://creativecommons.org/licenses/by/4.0/

(c) (i) Open Access

\section{Abstract}

Surface water samples and lake bed sediments were collected and analyzed from Gosaikunda Lake within Langtang National Park $\left(28^{\circ} 05^{\prime} \mathrm{N}, 8^{\circ} 25^{\prime} \mathrm{E}\right.$; $4380 \mathrm{~m}$ a.s.l.) in the central Himalayan region of Nepal during fall 2011. The major cations and anions in equivalents were present in the following order: $\mathrm{Ca}^{2+} \gg \mathrm{Na}^{+} \gg \mathrm{Mg}^{2+}>\mathrm{K}^{+} \gg \mathrm{NH}_{4}^{+}$and $\mathrm{SO}_{4}^{2-} \gg$ Alkalinity $\gg \mathrm{Cl}^{-} \gg \mathrm{F}^{-}>\mathrm{NO}_{3}^{-}$, respectively. Sulfide oxidation coupled with carbonate dissolution and aluminosilicate dissolution appeared to be the dominant geochemical processes determining lake water dissolved ions. Sulfate concentration was much higher than the alkalinity which is in contrast to glacier meltwater within the same landscape. Alkalinity primarily as bicarbonate contributes $\mathbf{8 8 . 6 \%}$ to the total dissolved inorganic carbon (DIC) followed by carbon dioxide $\left(\mathrm{CO}_{2}\right)$ and carbonate $\left(\mathrm{CO}_{3}\right)$ in surface water samples. Organic carbon contributes $0.3 \%$ to $5.4 \%$ to the sediments and the organic matter is predominantly of aquatic origin. The lake is under saturated with carbon dioxide and the average partial pressure of carbon dioxide $\left(\mathrm{pCO}_{2}\right)$ appeared quite low $(43.4 \mu \mathrm{atm})$. Overall, natural biogeochemical processes regulate the chemical species within the lake ecosystem. The lake is oligotrophic, however, nutrients and dissolved organic carbon (DOC) concentrations are enhanced at the near shore sites close to the tracking trail.

\section{Keywords}

Gosaikunda, High Himalaya, Langtang, Geochemical Processes, Nutrients

\footnotetext{
"Corresponding author.
} 


\section{Introduction}

Global warming has strong influence on water resources throughout the world and particularly in the central Himalayan region in Nepal. There are many lakes at high altitudes in Nepal including Tilicho Lake, one of the highest lakes in the world. The anthropogenic impact seems negligible within the high altitude region in Nepal but natural geochemical processes seem to control lake chemistry. Tourism and aeolian transport may have minor impacts on surface water chemistry. Generally, the chemistry of surface water can be impacted by three major processes: evaporation-crystallization, precipitation and geochemical processes related to rock weathering [1]-[4]. The transport of solute fluxes and ion concentrations derived from glaciers are high in the Himalayan region [5]-[14]. In recent years there have been some documented reports about the chemistry and biology of lakes of glacierized basins in the high Himalayan and lesser Himalayan landscape [6] [15]-[24] but the controlling mechanisms of biogeochemical processes within high Himalayan lakes have not been documented yet especially from the central Himalayan region in Nepal. The main objective of this paper is to report the major chemical parameters including nutrients and carbonic species present in a high altitude lake within Langtang National Park in central Himalaya and to evaluate the regulating factors including geochemical processes of these chemical parameters within the lake.

\section{Study Area}

This research was conducted in Gosaikunda Lake in the high Himalaya within Langtang National Park in central Nepal (Figure 1). The Gosaikunda lake area comprises 108 different sized lakes with an area of $10.30 \mathrm{~km}^{2}$ and is located about $42 \mathrm{~km}$ north of Kathmandu valley at $4380 \mathrm{~m}$ asl. The Gosaikunda is the largest lake within Gosaikunda area with a mean depth of about $12 \mathrm{~m}$. This site is designated as a Ramsar site in 2007 and has been a great place of interest for visitors and local people [25]. The central Himalayan region including Langtang basin is underlain by high-grade metamorphic rocks with traces of igneous rocks [26]. Based on the bedrock composition of rock samples from the same region in Langtang basin the following minerals have been detected by

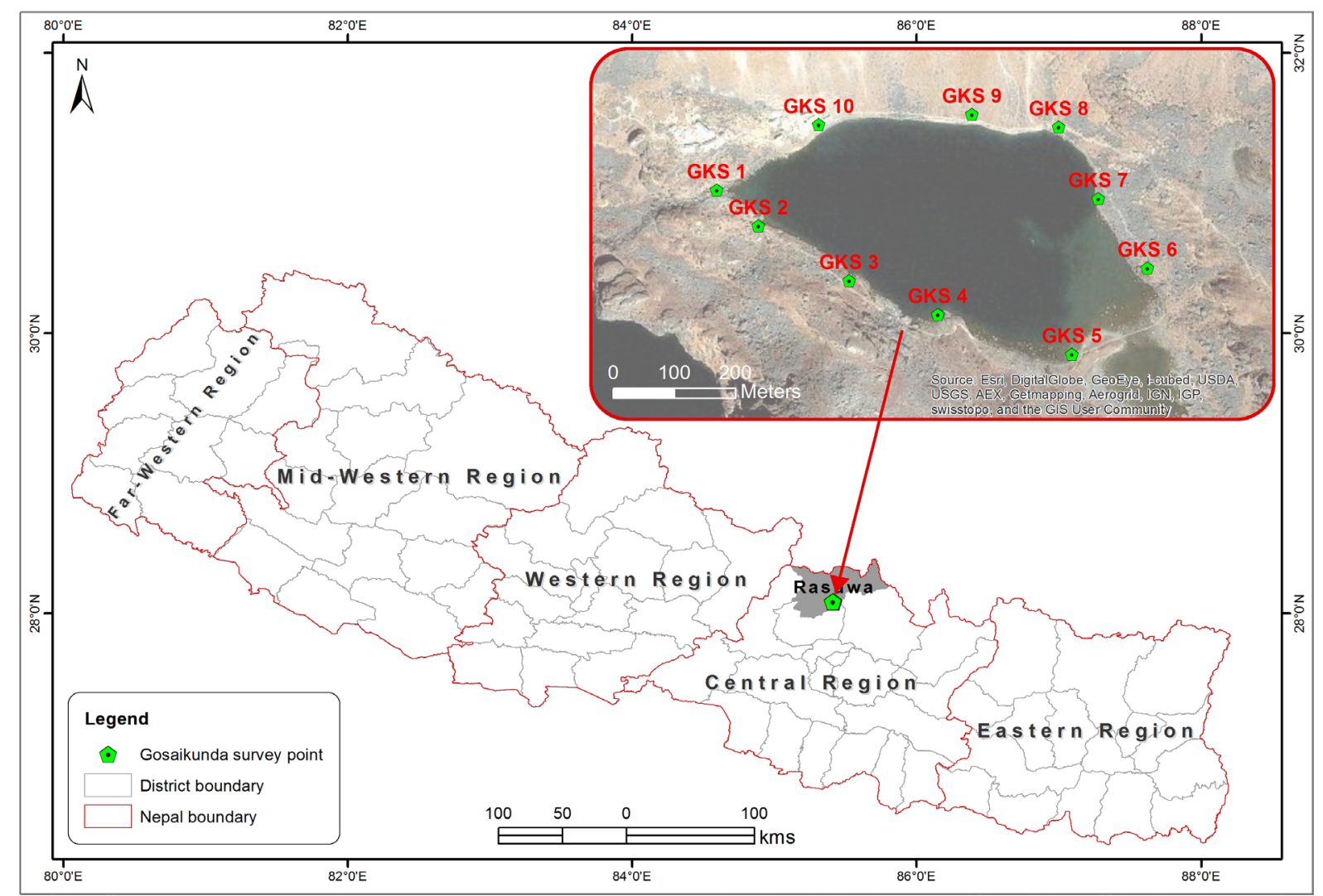

Figure 1. Map of sampling sites of Gosaikunda lake within Langtang National Park in Central Nepal. 
X-ray fluorescence analysis: biotite, quartz, plagioclase, muscovite, alkali feldspar, ilmenite and sillimanite [7]. Grey phyllites and grilstones with conglomerates with grey calcareous slates and carbonates, thick beds of siliceous dolomites are found in high central Himalayan region [27] [28]. The dominant soils are cryothents, cryumbrepts, and lithic types of soils [29]. Bhatt et al. [6] reported the presence of sulfide bearing minerals such as pyrite, galena, sphalerite and chalcopyrite within Langtang basin. The Gosaikunda lake is frozen nearly for six months during the winter season. Precipitation occurs mainly as snow fall except during summer and the monsoon seasons.

\section{Materials and Methods}

\subsection{Sample Collection}

Water samples were collected from ten sites during autumn 2011 from Gosaikunda Lake. Sediment samples from the lake were also collected from different positions in order to evaluate its organic matter contents and source. Samples were collected during day time but temperature was quite low $\left(-0.05^{\circ} \mathrm{C}\right)$ due to snow fall. Lake is frozen nearly for six months and there may not be much difference in chemistry during pre-monsoon and post-monsoon season however concentrations may vary slightly during monsoon season but the concentration trends (geochemical processes) will remain the same. Water samples were filtered in the field through a precombusted glass micro fiber filter (Whatmann GF/F with a pore size $0.7 \mu \mathrm{m}$ ). Water samples were collected in $100 \mathrm{~mL}$ acid-washed polyethylene bottles and refrigerated in Kathmandu and brought as frozen samples to the University of Hamburg for analysis. For dissolved silica analysis, $30 \mathrm{~mL}$ water sample was taken in polyethylene bottles and refrigerated in Kathmandu and sent as unfrozen samples to Hamburg. The authors used polycarbonate microfiber filter (with a pore size of $0.7 \mu \mathrm{m}$ ) to filter water for the analysis of major ions and dissolved silica. Thirty milliliter of water samples were taken in glass vials for dissolved organic carbon (DOC) and total dissolved nitrogen (TDN) analysis with $30 \mu \mathrm{l}$ phosphoric acid added just after the filtration through a pre-combusted glass micro fiber filter (Whatmann GF/F with a pore size $0.7 \mu \mathrm{m}$ ) in the field. DOC samples were kept refrigerated in Kathmandu and brought frozen to Hamburg for analysis. Suspended sediment (SS) was filtered on pre-weighted filter paper. Physical parameters such as water temperature, electrical conductivity (EC) and $\mathrm{pH}$ were measured in the field by thermometer, EC meter-Hanna and $\mathrm{pH}$ meter-Hanna respectively.

\subsection{Analytical Methods}

Suspended sediment concentration was calculated based on the pre-weighted $47 \mathrm{~mm}$ GF/F filter after drying in a vacuum oven at $40^{\circ} \mathrm{C}$ for $48 \mathrm{hr}$ by the gravimetric method. The samples were analyzed for major cations $\left(\mathrm{Na}^{+}\right.$, $\mathrm{K}^{+}, \mathrm{Mg}^{2+}$ and $\left.\mathrm{Ca}^{2+}, \mathrm{NH}_{4}^{+}\right)$, major anions $\left(\mathrm{Cl}^{-}, \mathrm{SO}_{4}^{2-}, \mathrm{PO}_{4}^{3-}, \mathrm{NO}_{3}^{-}\right)$, DOC, TDN, and dissolved silica. The dissolved silica $\left(\mathrm{SiO}_{2}\right)$ was analyzed by spectrophotometer DR 3800 (HACH Company) with the standard molybdenum blue 8185 method. Major cations $\left(\mathrm{Na}^{+}, \mathrm{K}^{+}, \mathrm{Mg}^{2+}, \mathrm{Ca}^{2+}\right.$, and $\left.\mathrm{NH}_{4}^{+}\right)$were determined by (Compact IC pro-cation) chromatography and major anions $\left(\mathrm{F}^{-}, \mathrm{Cl}^{-}, \mathrm{NO}_{2}^{-}, \mathrm{NO}_{3}^{-}\right.$, and $\mathrm{SO}_{4}^{2-}$ ) were determined by (Compact IC pro-anion) chromatography. The DOC and TDN were measured with high temperature Pt-catalyzed combustion using a Shimazdu TOC- $\mathrm{V}_{\mathrm{CSH}}$ for all water samples. The dissolved organic nitrogen (DON) was calculated by subtracting inorganic nitrogen from TDN. The parameters such as $\mathrm{pH}$, EC and water temperature were measured at the time of sampling in the field. The standard method was used for the measurement of alkalinity [30]. The computer program PhreeqC was used to estimate all inorganic carbon species [Dissolved Inorganic Carbon (DIC), $\mathrm{HCO}_{3}, \mathrm{CO}_{3}$, and $\mathrm{pCO}_{2}$ ]. The total carbon and nitrogen (TC, TN) content in sediment samples collected from the Gosaikunda lake were measured by using a Carlo Erba NA 1500 Elemental Analyzer; and total organic carbon (TOC) was measured after pre-treatment with $2 \mathrm{~N} \mathrm{HCl}$. The standard deviation for duplicate analyses was $0.15 \%$ and $0.005 \%$ respectively for carbon and nitrogen. Carbonate carbon $\left(\mathrm{C}_{\text {carb }}\right)$ was calculated by subtracting organic carbon from total carbon. Most $\mathrm{C}_{\text {carb }}$ were within the error range of the method and some thus yielded negative concentrations of $\mathrm{C}_{\text {carb }}$ and these values were adjusted to $0 \%$. Stable isotopes of carbon and nitrogen were measured with a Finnigan MAT 252 gas isotope mass spectrometer after high-temperature flash combustion in a Carlo Erba NA-2500 elemental analyzer at $1100^{\circ} \mathrm{C}$. The isotopic values carbon and nitrogen are expressed as $\delta^{13} \mathrm{C}(\%)$ and $\delta^{15} \mathrm{~N}(\%)$ respectively.

$$
\delta^{13} \mathrm{C}(\%)=\left[\left(\mathrm{R}_{\text {sample }} / \mathrm{R}_{\text {std }}\right)-1\right] \times 10^{3}
$$




$$
\delta^{15} \mathrm{~N}(\%)=\left[\left(\mathrm{R}_{\text {sample }} / \mathrm{R}_{\text {std }}\right)-1\right] \times 10^{3}
$$

where $\mathrm{R}$ is the ratios of ${ }^{13} \mathrm{C} /{ }^{12} \mathrm{C}$ for Equation (1) and ${ }^{15} \mathrm{~N} /{ }^{14} \mathrm{~N}$ for Equation (2). The standards were PDB (PeeDee Formation Belemnite Limestone) as reference standard for $\delta^{13} \mathrm{C}(\%)$ and air for $\delta^{15} \mathrm{~N}(\%)$. The two reference standards were IAEA-N-1 and IAEA-N-2 of the International Atomic Energy Agency (IAEA). The authors used a sediment standard as a working standard for $\delta^{15} \mathrm{~N}(\%)$. The mean deviation was $0.2(\%)$ for the duplicate measurement of samples and analytical precision was better than 0.1 (\%) for the replicate measurement of a reference standard. The authors have corrected sea-salt contributions to the following major chemical parameters: $\mathrm{Na}^{+}, \mathrm{K}^{+}, \mathrm{Mg}^{2+}, \mathrm{Ca}^{2+}$ and $\mathrm{SO}_{4}^{2-}$ by using the molar ratios of different elements relative to marine aerosols (chloride as a reference parameter) in order to evaluate the role of chemical weathering on the chemistry of the lake [31]-[34]. Sea-salt corrected chemical parameters are presented with an asterisk $(*)$ throughout the manuscript.

\section{Results}

\subsection{Physical Parameters}

Air and Water Temperature, Electrical Conductivity, $\mathrm{pH}$ and Suspended Sediment

The average air temperature was $-0.05^{\circ} \mathrm{C}$ at the time of sampling and ranged between $-0.8^{\circ} \mathrm{C}$ to $0.9^{\circ} \mathrm{C}$ among all sampling points. Average water temperature was $7.4^{\circ} \mathrm{C}$ and ranged from $5.8^{\circ} \mathrm{C}$ to $8.4^{\circ} \mathrm{C}$ at different sampling points within the lake (Table 1). The lowest water temperature appeared at the inlet point (GKS 5 - east facing point) probably due to input from glacier melt and the highest temperature appeared near the trail pint in the north (GKS 8-south facing site). The average electrical conductivity (EC) within the lake was $30 \mu \mathrm{S} \cdot \mathrm{cm}^{-1}$ with a range from $26 \mu \mathrm{S} \cdot \mathrm{cm}^{-1}$ to $40 \mu \mathrm{S} \cdot \mathrm{cm}^{-1}$ and slightly higher values at the sites where rock walls present and lowest at sites where weathered soils and boulders were present (Table 1). Based on the EC concentration the landscape position has a strong control on solute chemistry within the Gosaikund lake. The average $\mathrm{pH}$ was 7.56 with the range from 7.06 to 8.81 in Gosaikunda lake during fall 2011 (Table 1). The pH at stations GKS 1 to GKS 5 was higher than at stations GKS 6 to GKS10 in the northern part of the lake (Figure 2). The average suspended sediment was $5.23 \mathrm{mg} \cdot \mathrm{L}^{-1}$ and appeared highest at the outlet point (GKS 1) and the locations near the temple and the tracking trail and lowest at deep sampling sites (GKS3, GKS4, GKS6, GKS7) with the range from $1.33 \mathrm{mg} \cdot \mathrm{L}^{-1}$ to $32.83 \mathrm{mg} \cdot \mathrm{L}^{-1}$ (Table 1 ).

\subsection{Chemical Parameters}

\subsubsection{Spatial Variation in Chemical Composition}

The variation pattern of all measured chemical species within Gosaikunda lake is presented in Table 2. Most of

Table 1. Physical parameters of sampling points within Gosaikunda lake during fall 2011.

\begin{tabular}{cccccccccc}
\hline $\begin{array}{c}\text { Sample } \\
\text { Name }\end{array}$ & Site Information & Latitude & Longitude & $\begin{array}{c}\text { Elevation } \\
\mathrm{m}\end{array}$ & $\begin{array}{c}\mathrm{SS} \\
\mathrm{mg} / \mathrm{L}\end{array}$ & $\begin{array}{c}\mathrm{EC} \\
\mu \mathrm{S} / \mathrm{cm}\end{array}$ & $\mathrm{pH}$ & WT $\left({ }^{\circ} \mathrm{C}\right)$ & $\mathrm{AT}\left({ }^{\circ} \mathrm{C}\right)$ \\
\hline GKS1 & Western-Outlet Point/Shallow & $28^{\circ} 04^{\prime} 59.7^{\prime \prime}$ & $85^{\circ} 24^{\prime} 36.9^{\prime \prime}$ & 4394 & 32.83 & 27 & 8.81 & 7.6 & -0.3 \\
GKS2 & Southern-Big Boulders/Deep & $28^{\circ} 04^{\prime} 58.0^{\prime \prime}$ & $85^{\circ} 24^{\prime} 39.1^{\prime \prime}$ & 4392 & 3.33 & 40 & 8.20 & 7.4 & 0.7 \\
GKS3 & Southern-Coubles/Deep & $28^{\circ} 04^{\prime} 55.4^{\prime \prime}$ & $85^{\circ} 24^{\prime} 43.9^{\prime \prime}$ & 4410 & 1.83 & 31 & 7.60 & 6.8 & 0.3 \\
GKS4 & Southern-Steep Slope/Deep & $28^{\circ} 04^{\prime} 53.8^{\prime \prime}$ & $85^{\circ} 24^{\prime} 48.6^{\prime \prime}$ & 4411 & 1.83 & 29 & 7.80 & 7.7 & 0.2 \\
GKS5 & Eastern-Coubles/Shallow & $28^{\circ} 04^{\prime} 51.9^{\prime \prime}$ & $85^{\circ} 24^{\prime} 55.7^{\prime \prime}$ & 4402 & 1.83 & 27 & 7.32 & 5.8 & -0.1 \\
GKS6 & Northern-Boulders/Shallow & $28^{\circ} 04^{\prime} 56.0^{\prime \prime}$ & $85^{\circ} 24^{\prime} 59.7^{\prime \prime}$ & 4398 & 1.33 & 31 & 7.25 & 7.6 & -0.8 \\
GKS7 & Northern-Boulders/Shallow & $28^{\circ} 04^{\prime} 59.3^{\prime \prime}$ & $85^{\circ} 24^{\prime} 57.1^{\prime \prime}$ & 4401 & 1.33 & 35 & 7.25 & 7.4 & 0.9 \\
GKS8 & Northern-Trail to North Side & $28^{\circ} 05^{\prime} 02.7^{\prime \prime}$ & $85^{\circ} 24^{\prime} 55.0^{\prime \prime}$ & 4395 & 2.17 & 26 & 7.19 & 8.4 & -0.1 \\
GKS9 & Northern-Big Boulders & $28^{\circ} 05^{\prime} 03.3^{\prime \prime}$ & $85^{\circ} 24^{\prime} 50.4^{\prime \prime}$ & 4397 & 2.58 & 27 & 7.06 & 7.5 & -0.6 \\
GKS10 & Northern-Near Temple & $28^{\circ} 05^{\prime} 02.8^{\prime \prime}$ & $85^{\circ} 24^{\prime} 42.3^{\prime \prime}$ & 4397 & 3.17 & 28 & 7.16 & 7.4 & -0.7 \\
\hline
\end{tabular}




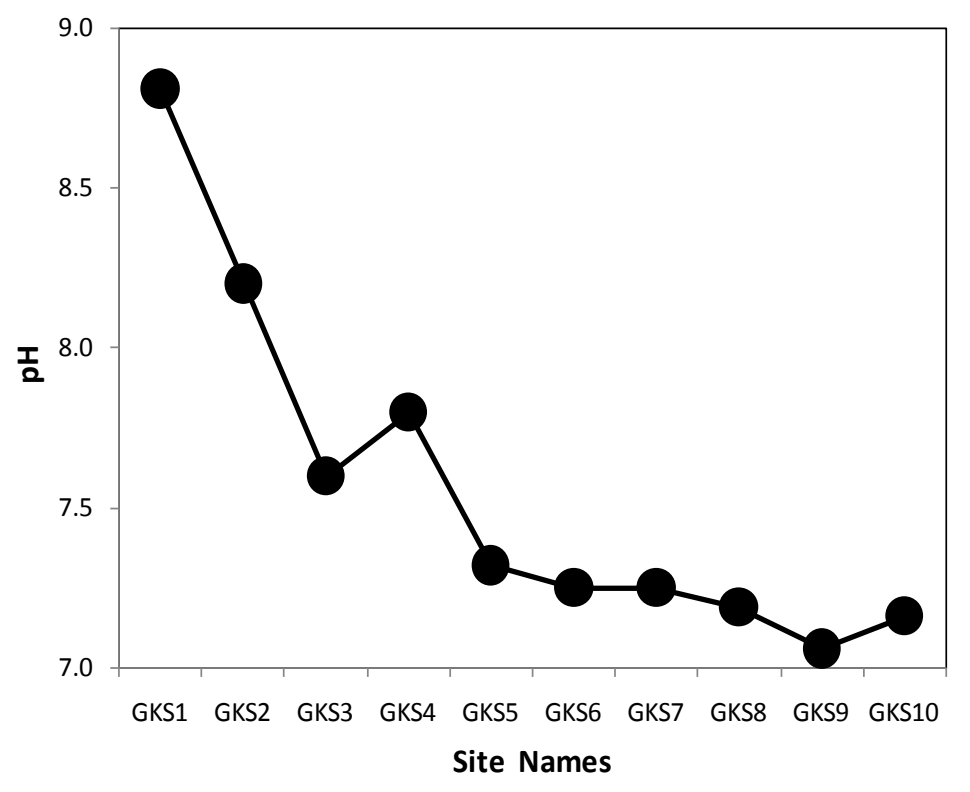

Figure 2. Spatial variations of $\mathrm{pH}$ in Gosaikunda lake within Langtang National Park in central Nepal.

Table 2. Spatial variation in chemical compositions of Gosaikunda lake during fall 2011.

\begin{tabular}{ccccccccccccccc}
\hline $\begin{array}{c}\text { Sample } \\
\text { ID }\end{array}$ & $\begin{array}{c}\mathrm{H}^{+} \\
\mathrm{ng} / \mathrm{L}\end{array}$ & $\begin{array}{c}\mathrm{DOC} \\
\mathrm{mg} / \mathrm{L}\end{array}$ & $\begin{array}{c}\mathrm{TDN} / \mathrm{m} \\
\mathrm{mg} / \mathrm{Alkalinity}\end{array}$ & $\begin{array}{c}\mathrm{F} \\
\mu \mathrm{eq} / \mathrm{L}\end{array}$ & $\begin{array}{c}\mathrm{Cl} \\
\mu \mathrm{eq} / \mathrm{L}\end{array}$ & $\begin{array}{c}\mathrm{NO}_{3} \\
\mu \mathrm{L}\end{array}$ & $\begin{array}{c}\mathrm{SO}_{4} \\
\mu \mathrm{eq} / \mathrm{L}\end{array}$ & $\begin{array}{c}\mathrm{NH}_{4} \\
\mu \mathrm{eq} / \mathrm{L}\end{array}$ & $\begin{array}{c}\mathrm{Na} / \mathrm{L} \\
\mu \mathrm{eq} / \mathrm{L}\end{array}$ & $\begin{array}{c}\mathrm{K} \\
\mu \mathrm{eq} / \mathrm{L}\end{array}$ & $\begin{array}{c}\mathrm{Mg} \\
\mu \mathrm{eq} / \mathrm{L}\end{array}$ & $\begin{array}{c}\mathrm{Ca} \\
\mu \mathrm{eq} / \mathrm{L}\end{array}$ & $\begin{array}{c}\mathrm{Si} \\
\mu \mathrm{eq} / \mathrm{L}\end{array}$ \\
\hline GKS 1 & 1.56 & 1.72 & 0.27 & 19.98 & 0.684 & 2.45 & 0.071 & 88.83 & 11.64 & 11.35 & 6.16 & 4.61 & 37.52 & 184.21 \\
GKS 2 & 6.36 & 1.48 & 0.17 & 19.98 & 0.790 & 3.27 & 0.071 & 88.33 & 7.37 & 12.22 & 5.45 & 8.14 & 39.57 & 176.32 \\
GKS 3 & 25.32 & 1.70 & 0.23 & 19.98 & 0.842 & 6.88 & 0.000 & 85.84 & 4.88 & 15.49 & 11.74 & 10.53 & 35.73 & 181.58 \\
GKS 4 & 15.97 & 1.44 & 0.22 & $<19.98$ & 0.737 & 6.54 & 0.071 & 85.03 & 0.00 & 16.44 & 6.88 & 9.79 & 35.18 & 178.95 \\
GKS 5 & 48.24 & 1.67 & 0.21 & 19.98 & 0.684 & 3.02 & 0.000 & 85.71 & 0.00 & 12.83 & 5.06 & 9.05 & 37.57 & 183.16 \\
GKS 6 & 56.68 & 2.20 & 0.29 & $<19.98$ & 1.000 & 5.90 & 0.071 & 100.50 & 0.00 & 16.88 & 5.45 & 10.28 & 42.81 & 204.74 \\
GKS 7 & 56.68 & 2.12 & 0.36 & $<19.98$ & 0.947 & 7.11 & 0.071 & 118.59 & 0.00 & 20.66 & 9.26 & 14.48 & 42.91 & 240.53 \\
GKS 8 & 65.08 & 1.60 & 0.20 & $<19.98$ & 0.842 & 2.79 & 0.071 & 89.64 & 0.00 & 11.92 & 5.96 & 9.30 & 28.94 & 191.05 \\
GKS 9 & 87.78 & 2.08 & 0.23 & $<19.98$ & 0.842 & 8.15 & 0.071 & 87.40 & 8.20 & 18.23 & 5.98 & 0.00 & 37.67 & 180.00 \\
GKS 10 & 69.73 & 1.93 & 0.26 & $<19.98$ & 0.737 & 3.36 & 0.071 & 87.40 & 3.94 & 13.14 & 6.09 & 0.00 & 37.52 & 187.37 \\
\hline
\end{tabular}

the chemical parameters showed higher concentrations along the northern lake shore south facing sites (GKS 6 to GKS 10) with highest concentration at GKS7, which is the sampling point close to the tracking trail. The chemical compositions of major cation and anion in equivalent per liter were $\mathrm{Ca}^{2+} \gg \mathrm{Na}^{+} \gg \mathrm{Mg}^{2+}>\mathrm{K}^{+} \gg \mathrm{NH}_{4}^{+}$ and $\mathrm{SO}_{4}^{2-} \gg \mathrm{HCO}_{3}^{-} \gg \mathrm{Cl}^{-} \gg \mathrm{F}^{-}>\mathrm{NO}_{3}^{-}$respectively within Gosaikunda lake. The higher concentrations of protons were observed along the northern lake shore (GKS 6 to GKS 10). The average proton concentration was $43.34 \mathrm{ng} \cdot \mathrm{L}^{-1}$ with a range from $1.56 \mathrm{ng} \cdot \mathrm{L}^{-1}$ to $87.78 \mathrm{ng} \cdot \mathrm{L}^{-1}$ among all sampling points. The contribution of nitrate concentration to the sum of total anion was negligible and phosphate was not detected in any of the samples. The alkalinity of the lake was low $\left(<20 \mu \mathrm{eq} \cdot \mathrm{L}^{-1}\right)$ at all sampling sites probably because of low temperature, absence of vegetation and low denudation rate within the landscape. Sulfate was the dominant chemical species (78\% contribution to the total anions) with the average concentration of $92 \mu \mathrm{eq} \cdot \mathrm{L}^{-1}$ and concentrations varied from $85.1 \mu \mathrm{eq} \cdot \mathrm{L}^{-1}$ to $118.6 \mu \mathrm{eq} \cdot \mathrm{L}^{-1}$ among all sampling sites. The high content of sulfate seems to regulate chemical concentrations within the Gosiakunda lake. Calcium is the dominant cation (56.63\% contribution to 
sum of base cations) with a range between $28.94 \mu \mathrm{eq} \cdot \mathrm{L}^{-1}$ and $42.91 \mu \mathrm{eq} \cdot \mathrm{L}^{-1}$ among all sites within Gosaikunda lakes. Sodium is the second dominant cation suggesting aluminosilicate dissolution as its major source. The highest amount of ammonium was measured at the outlet points and its surrounding areas (Table 2). Highest content of silicon is found at sites GKS 6 to GKS 8 and its variation trends are similar to the pattern of sulfate ion (Figure 3). The average silicon concentration within Gosaikunda lake is $190.8 \mu \mathrm{eq} \cdot \mathrm{L}^{-1}$ and ranges between 176.32 to $240.53 \mu \mathrm{eq} \cdot \mathrm{L}^{-1}$ at different locations within the lake. The variation of silicon is quite consistent with the variation pattern of sulfate ions after sea-salt corrections and show a strong correlation coefficient of $\mathrm{R}^{2}=$ 0.96 and a probability of $\mathrm{p}<0.0001$, respectively (Figure 4).

Chemical compositions of major chemical species and molar elemental ratios after sea-salt correction are compiled in Table 3. The contribution of chemical species from chemical weathering processes to their respective concentration are in the following order: $\mathrm{SO}_{4}^{2-}(99.44 \%)>\mathrm{Ca}^{2+}(99.50 \%)>\mathrm{K}^{+}(98.62 \%)>\mathrm{Mg}^{2+}(90.32 \%)$

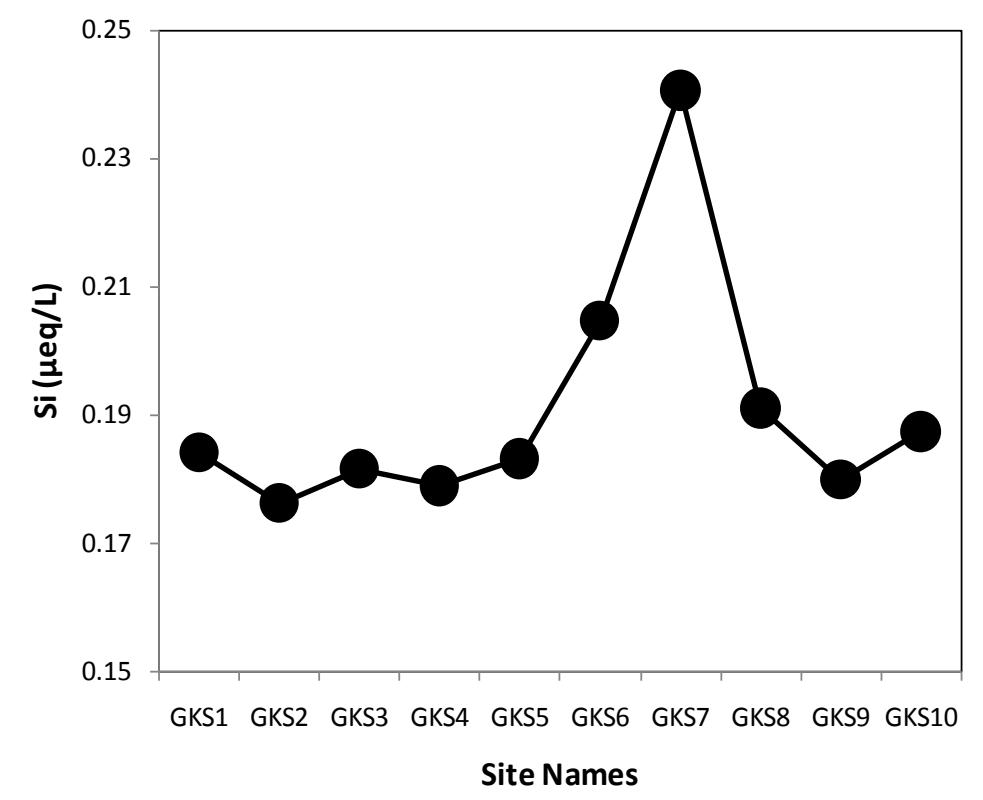

Figure 3. Spatial variations of silicon in Gosaikunda lake within Langtang National Park in central Nepal.

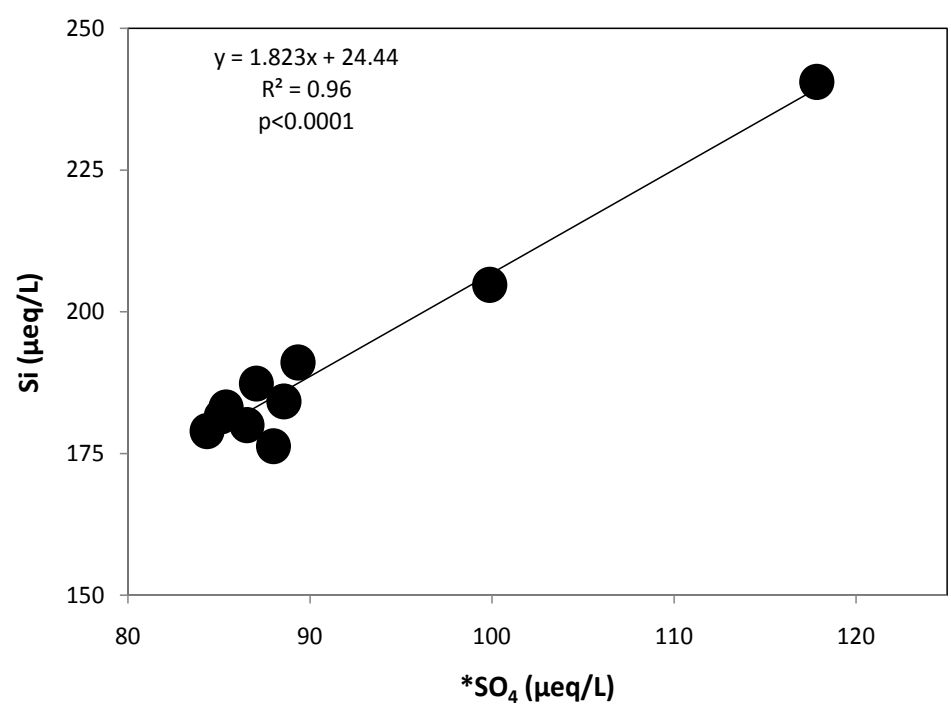

Figure 4. Relationship between silicon and sea-salt corrected sulfate in Gosaikunda lake within Langtang National Park in central Nepal. 
Table 3. Chemical compositions of major chemical species and elemental ratios after sea-salt correction in Gosaikunda lake during fall 2011.

\begin{tabular}{|c|c|c|c|c|c|c|c|c|c|c|}
\hline $\begin{array}{l}\text { Sample } \\
\text { ID }\end{array}$ & $\begin{array}{r}{ }^{*} \mathrm{SO}_{4} \\
\mu \mathrm{eq} / \mathrm{L}\end{array}$ & $\begin{array}{c}{ }^{*} \mathrm{Na} \\
\mu \mathrm{eq} / \mathrm{L}\end{array}$ & $\begin{array}{c}{ }^{*} \mathrm{~K} \\
\mu \mathrm{eq} / \mathrm{L}\end{array}$ & $\begin{array}{r}{ }^{*} \mathrm{Mg} \\
\mu \mathrm{eq} / \mathrm{L}\end{array}$ & $\begin{array}{c}{ }^{*} \mathrm{Ca} \\
\mu \mathrm{eq} / \mathrm{L}\end{array}$ & $\begin{array}{c}{ }^{*} \text { Sbcat } \\
\mu e q / L\end{array}$ & $\begin{array}{c}{ }^{*} \mathrm{Ca} /{ }^{*} \mathrm{Na} \\
\text { molar }\end{array}$ & $\begin{array}{l}{ }^{*} \mathrm{Mg} / \mathrm{Na} \\
\text { molar }\end{array}$ & $\begin{array}{l}{ }^{*} \mathrm{~K} /{ }^{*} \mathrm{Na} \\
\text { molar }\end{array}$ & $\begin{array}{c}{ }^{*} \mathrm{SO}_{4} /{ }^{*} \mathrm{Na} \\
\text { molar }\end{array}$ \\
\hline GKS 1 & 88.58 & 9.24 & 6.12 & 4.13 & 37.43 & 56.91 & 2.03 & 0.223 & 0.662 & 4.79 \\
\hline GKS 2 & 87.99 & 9.40 & 5.39 & 7.50 & 39.45 & 61.74 & 2.10 & 0.399 & 0.573 & 4.68 \\
\hline GKS 3 & 85.12 & 9.55 & 11.61 & 9.18 & 35.47 & 65.81 & 1.86 & 0.481 & 1.215 & 4.46 \\
\hline GKS 4 & 84.35 & 10.80 & 6.76 & 8.51 & 34.93 & 61.00 & 1.62 & 0.394 & 0.626 & 3.90 \\
\hline GKS 5 & 85.40 & 10.23 & 5.01 & 8.46 & 37.46 & 61.16 & 1.83 & 0.413 & 0.489 & 4.17 \\
\hline GKS 6 & 99.88 & 11.80 & 5.34 & 9.13 & 42.59 & 68.85 & 1.81 & 0.387 & 0.452 & 4.23 \\
\hline GKS 7 & 117.85 & 14.53 & 9.12 & 13.09 & 42.65 & 79.39 & 1.47 & 0.450 & 0.628 & 4.05 \\
\hline GKS 8 & 89.35 & 9.51 & 5.91 & 8.75 & 28.84 & 53.00 & 1.52 & 0.460 & 0.621 & 4.70 \\
\hline GKS 9 & 86.55 & 11.20 & 5.83 & bdl & 37.37 & 52.80 & 1.67 & nd & 0.521 & 3.86 \\
\hline GKS 10 & 87.05 & 10.24 & 6.02 & bdl & 37.40 & 53.01 & 1.83 & nd & 0.588 & 4.25 \\
\hline
\end{tabular}

*Astersk represent sea-salt corrected values, bdl = below detection limit.

$>\mathrm{Na}^{+}$(72.48\%) suggesting chemical weathering of rocks as a dominant factor to control the chemistry of Gosaikunda lake. Sea-salt contribution of these major chemical species to the total concentration appeared negligible except for sodium and magnesium. The sum of calcium and magnesium after sea-salt correction showed a correlations with the sum of base cations after sea-salt correction with a correlation coefficient and probability of $\mathrm{R}^{2}=0.90$ and $\mathrm{p}<0.0001$ respectively (Figure 5) suggesting a contribution of calcite dissolution of $67 \%$ to the total concentration of cations.

\subsubsection{Spatial Variation in DOC, TDN and DIC Species}

The average dissolved organic carbon (DOC) concentration was $1.79 \mathrm{mg} \cdot \mathrm{L}^{-1}$ and showed variations between 1.44 to $2.20 \mathrm{mg} \cdot \mathrm{L}^{-1}$ within lake. The high concentrations of DOC appeared at sites GKS 6 - GKS 7 close to the trail from where humans and Yak cross and the sites GKS 9 and GKS 10 close to the temple from where flowers and leaves enter into the lake systems. The average TDN concentration was $0.24 \mathrm{mg} \cdot \mathrm{L}^{-1}$ and the concentration ranged between 0.17 and $0.36 \mathrm{mg} \cdot \mathrm{L}^{-1}$ within lake. The TDN showed spatial variations similar to those of DOC concentrations.

The dissolved inorganic carbon species except carbonate showed increasing concentrations from the sites GKS 1 to GKS 10 (Table 4). The average dissolved inorganic carbon (DIC) was $20.82 \mu \mathrm{mol} \cdot \mathrm{L}^{-1}$ and ranged from 8.6 to $25.1 \mu \mathrm{mol} \cdot \mathrm{L}^{-1}$. The carbon dioxide $\left(\mathrm{CO}_{2}\right)$ concentrations ranged from 0.04 to $5.23 \mu \mathrm{mol} \cdot \mathrm{L}^{-1}$ with an average concentration of $2.56 \mu \mathrm{mol} \cdot \mathrm{L}^{-1}$ while the carbonate $\left(\mathrm{CO}_{3}\right)$ showed decreasing concentrations from GKS 1 to GKS 10 ranging between 0.007 to $0.174 \mu \mathrm{mol} \cdot \mathrm{L}^{-1}$ with an average concentration of $0.038 \mu \mathrm{mol} \cdot \mathrm{L}^{-1}$. The average bicarbonate $\left(\mathrm{HCO}_{3}\right)$ concentration was $18.2 \mu \mathrm{mol} \cdot \mathrm{L}^{-1}$ with a range from 8.4 to $20 \mu \mathrm{mol} \cdot \mathrm{L}^{-1}$. The $\mathrm{HCO}_{3}$ contributes highest amounts to the total DIC and showed a strong relationship with DIC with a correlation coefficient and probability of $\mathrm{R}^{2}=0.92$ and $\mathrm{p}<0.0001$, respectively (Figure 6(a)). The average partial pressure of carbon dioxide $\left(\mathrm{pCO}_{2}\right)$ was $43.4 \mu \mathrm{atm}$ and its concentrations varied from 0.67 to $89 \mu \mathrm{atm}$. The wide variation in concentrations of $\mathrm{pCO}_{2}$ suggests that spatial variation in production and consumption of $\mathrm{pCO}_{2}$ regulate the geochemical processes within the lake (Figure 6(b)). The $\mathrm{pCO}_{2}$ showed strong relationship with $\mathrm{CO}_{3}$ and clearly indicates that the presence of $\mathrm{CO}_{3}$ neutralizes the acidity produced due to pyrite oxidation and hence $\mathrm{pCO}_{2}$ decreases during the course of chemical weathering within the lake (Figure 6(c)) although the contribution of $\mathrm{CO}_{3}$ to DIC seems negligible (only $0.31 \%$ ). Bicarbonate contributes highest (88.6\%), carbon dioxide contributes moderate $(11.03 \%)$ and carbonate contributes the least amount $(0.31 \%)$ to the total dissolved inorganic carbon and a very clear opposite concentration trend of bicarbonate and carbon dioxide suggests the conversion of carbon dioxide to bicarbonate during the dissolution processes (Figure 6(d)). 
Table 4. Inorganic carbon species in Gosaikunda lake during fall 2011.

\begin{tabular}{|c|c|c|c|c|c|c|}
\hline $\begin{array}{l}\text { Sample } \\
\text { ID }\end{array}$ & $\begin{array}{l}\text { Alkalinity } \\
(\mu \mathrm{mol} / \mathrm{L})\end{array}$ & $\begin{array}{c}\text { DIC } \\
(\mu \mathrm{mol} / \mathrm{L})\end{array}$ & $\begin{array}{c}\mathrm{CO}_{2} \\
(\mu \mathrm{mol} / \mathrm{L})\end{array}$ & $\begin{array}{c}\mathrm{HCO}_{3} \\
(\mu \mathrm{mol} / \mathrm{L})\end{array}$ & $\begin{array}{c}\mathrm{CO}_{3} \\
(\mu \mathrm{mol} / \mathrm{L})\end{array}$ & $\begin{array}{c}\mathrm{pCO}_{2} \\
(\mu \mathrm{atm})\end{array}$ \\
\hline GKS 1 & 19.9827 & 8.62 & 0.04 & 8.40 & 0.174 & 0.67 \\
\hline GKS 2 & 19.9827 & 17.60 & 0.33 & 17.17 & 0.087 & 5.58 \\
\hline GKS 3 & 19.9827 & 20.83 & 1.49 & 19.30 & 0.024 & 24.79 \\
\hline GKS 4 & $<19.9827$ & 19.85 & 0.90 & 18.90 & 0.038 & 15.47 \\
\hline GKS 5 & 19.9827 & 22.68 & 2.97 & 19.69 & 0.012 & 47.67 \\
\hline GKS 6 & $<19.9827$ & 23.04 & 3.34 & 19.69 & 0.011 & 57.04 \\
\hline GKS 7 & $<19.9828$ & 23.00 & 3.34 & 19.64 & 0.011 & 56.70 \\
\hline GKS 8 & $<19.9827$ & 23.54 & 3.77 & 19.75 & 0.010 & 66.40 \\
\hline GKS 9 & $<19.9827$ & 25.10 & 5.23 & 19.85 & 0.007 & 89.13 \\
\hline GKS 10 & $<19.9827$ & 23.95 & 4.15 & 19.78 & 0.009 & 70.47 \\
\hline
\end{tabular}

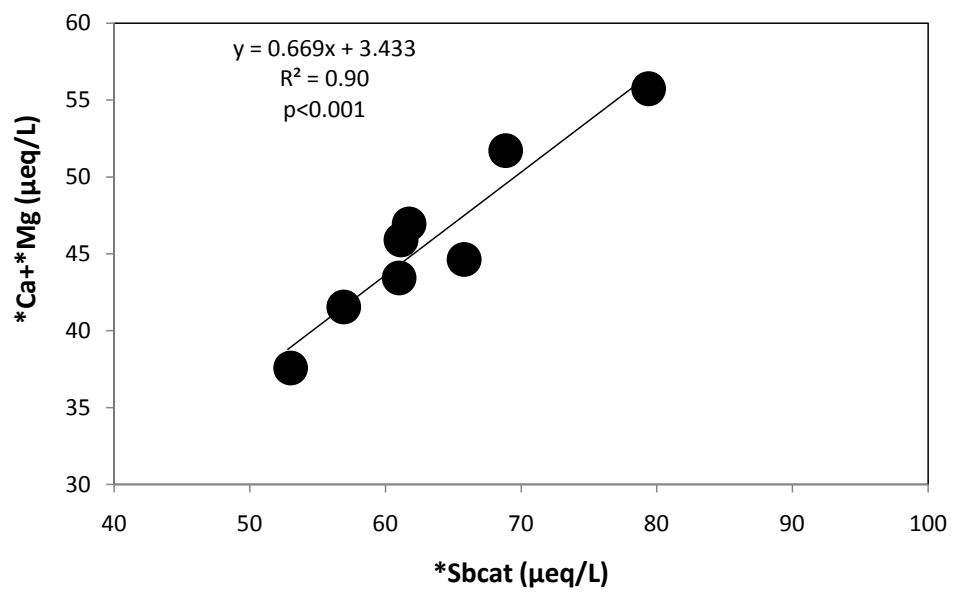

Figure 5. Relationship between sum of calcium and magnesium, and sum of base cations after sea-salt correction in Gosaikunda lake within Langtang National Park in central Nepal.

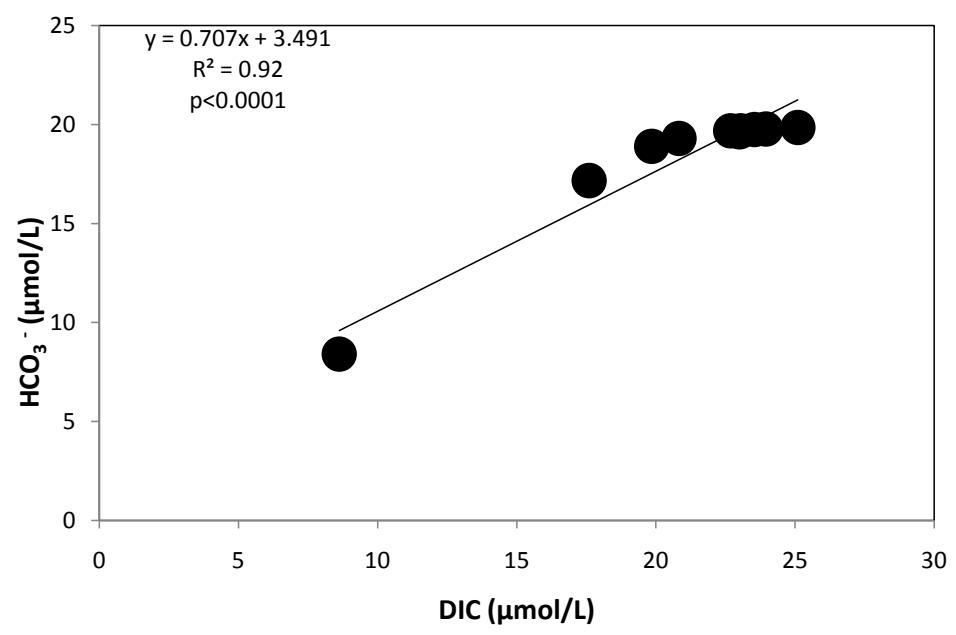

(a) 

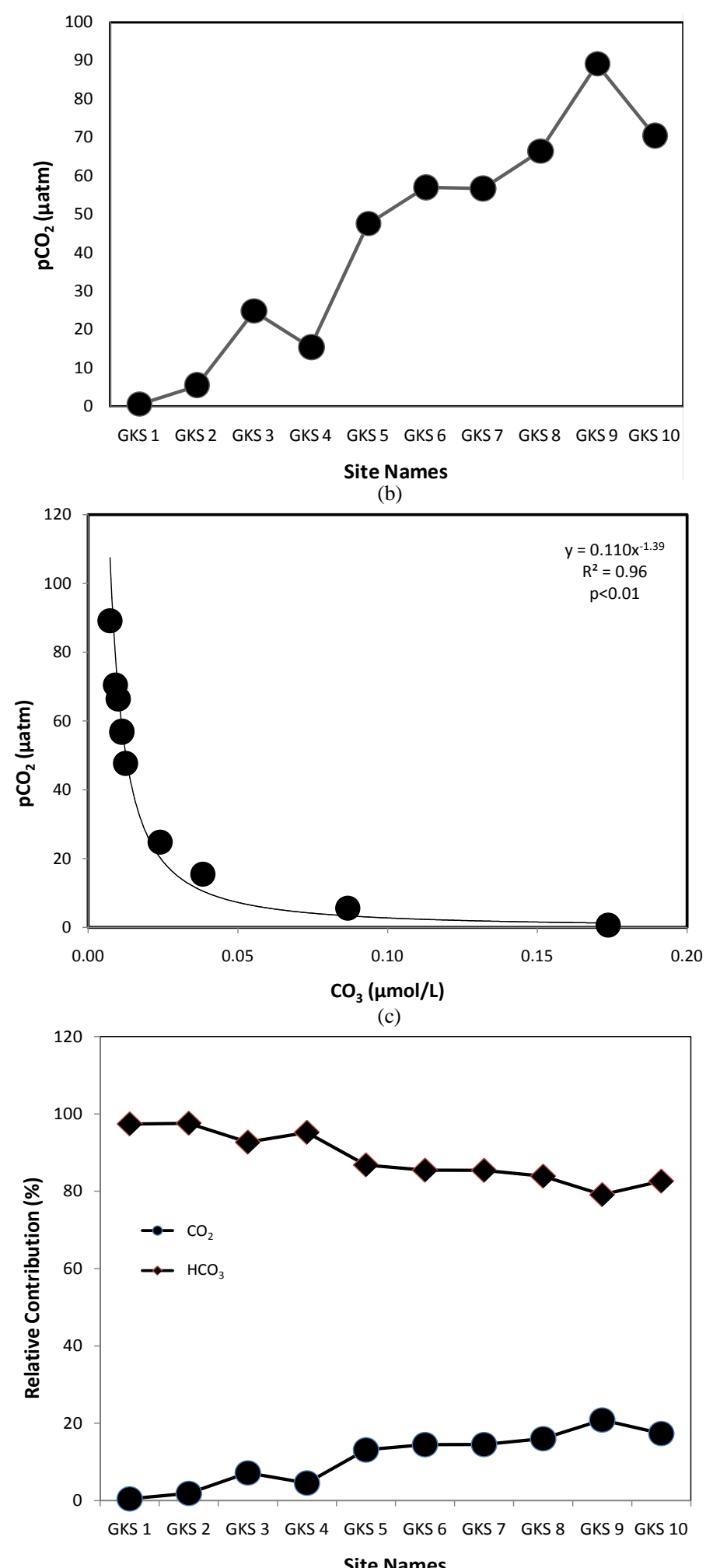

(d)

Figure 6. (a) Relationship between bicarbonate and DIC in Gosaikunda lake within Langtang National Park in central Nepal; (b) Spatial variations of $\mathrm{pCO}_{2}$ in Gosaikunda lake within Langtnag National Park in central Nepal; (c) Relationship between $\mathrm{pCO}_{2}$ and carbonate in Gosaikunda lake within Langtang National Park in central Nepal; (d) Relative contributions of inorganic carbon species to total DIC in Gosaikunda lake within Langtang National Park in central Nepal. 


\subsubsection{Spatial Variation in Total Nitrogen (TN) and Stable Carbon and Nitrogen Isotopes $\left(\delta^{13} \mathrm{C}\right.$ and} $\delta^{15} \mathrm{~N}$ ) and Total Particulate Organic Carbon (POC) in Lake Sediments

The carbon and nitrogen contents of the lake sediment of Gosaikunda are compiled in Table 5. The average POC concentration is $1.58 \%$ and the concentrations range between $0.35 \%$ to $5.5 \%$. Carbonate content is negligible in lake sediments as the lake water is carbonate under saturated. The average total nitrogen concentration is $0.14 \%$ with a range from $0.03 \%$ to $0.52 \%$. The average molar ratio of carbon to nitrogen $(\mathrm{C} / \mathrm{N})$ is 12.6 and the ratios vary from 10.6 to 16.4 . The average $\delta^{13} \mathrm{C}$ and $\delta^{15} \mathrm{~N}$ values are $-22.1 \%$ and $2.9 \%$ respectively. Stable isotopic ratios of $\delta^{13} \mathrm{C}$ and $\delta^{15} \mathrm{~N}$ vary between $-20 \%$ to $-25 \%$ and $0.7 \%$ o to $4.8 \%$, respectively. Total nitrogen content is significantly correlated with organic carbon content with a correlation coefficient and probability of $\mathrm{R}^{2}=$ 0.97 and $\mathrm{p}<0.0001$, respectively suggesting the same source for both of these elements within the lake sediment (Figure 7).

Table 5. Carbon and nitrogen contents in bed sediments of Gosaikunda lake during fall 2011.

\begin{tabular}{ccccccccc}
\hline $\begin{array}{c}\text { Sample } \\
\text { ID }\end{array}$ & $\begin{array}{c}\text { Total Carbon } \\
(\%)\end{array}$ & $\begin{array}{c}\text { Organic Carbon } \\
(\%)\end{array}$ & $\begin{array}{c}\text { Inorganic Carbon } \\
(\%)\end{array}$ & $\begin{array}{c}\mathrm{CaCO}_{3} \\
(\%)\end{array}$ & $\begin{array}{c}\text { Total Nitrogen } \\
(\%)\end{array}$ & $\begin{array}{c}\mathrm{C} / \mathrm{N} \text { Ratios } \\
\text { Molar }\end{array}$ & $\begin{array}{c}\delta^{13} \mathrm{c} \\
(\%)\end{array}$ & $\begin{array}{c}\delta^{15} \mathrm{~N} \\
(\%)\end{array}$ \\
\hline GKS 1 & 0.36 & 0.34 & 0.01 & 0.11 & 0.03 & 11.76 & -22.79 & 0.72 \\
GKS 2 & 3.60 & 3.56 & 0.04 & 0.36 & 0.25 & 16.39 & -23.65 & 4.33 \\
GKS 3 & 0.66 & 0.67 & 0.00 & 0.00 & 0.05 & 14.24 & -21.50 & 3.12 \\
GKS 4 & 0.64 & 0.66 & 0.00 & 0.00 & 0.06 & 13.05 & -21.03 & 3.38 \\
GKS 5 & 0.50 & 0.49 & 0.02 & 0.15 & 0.05 & 10.59 & -19.96 & 2.47 \\
GKS 6 & 1.35 & 1.29 & 0.06 & 0.50 & 0.13 & 11.89 & -20.45 & 2.13 \\
GKS 7 & 5.49 & 5.43 & 0.05 & 0.45 & 0.52 & 12.16 & -20.91 & 1.03 \\
GKS 8 & 1.94 & 2.07 & 0.00 & 0.00 & 0.20 & 11.79 & -21.73 & 3.15 \\
GKS 9 & 0.95 & 0.93 & 0.02 & 0.21 & 0.08 & 13.48 & -24.30 & 4.78 \\
GKS 10 & 0.35 & 0.32 & 0.03 & 0.23 & 0.03 & 11.03 & -24.99 & 3.77 \\
\hline
\end{tabular}

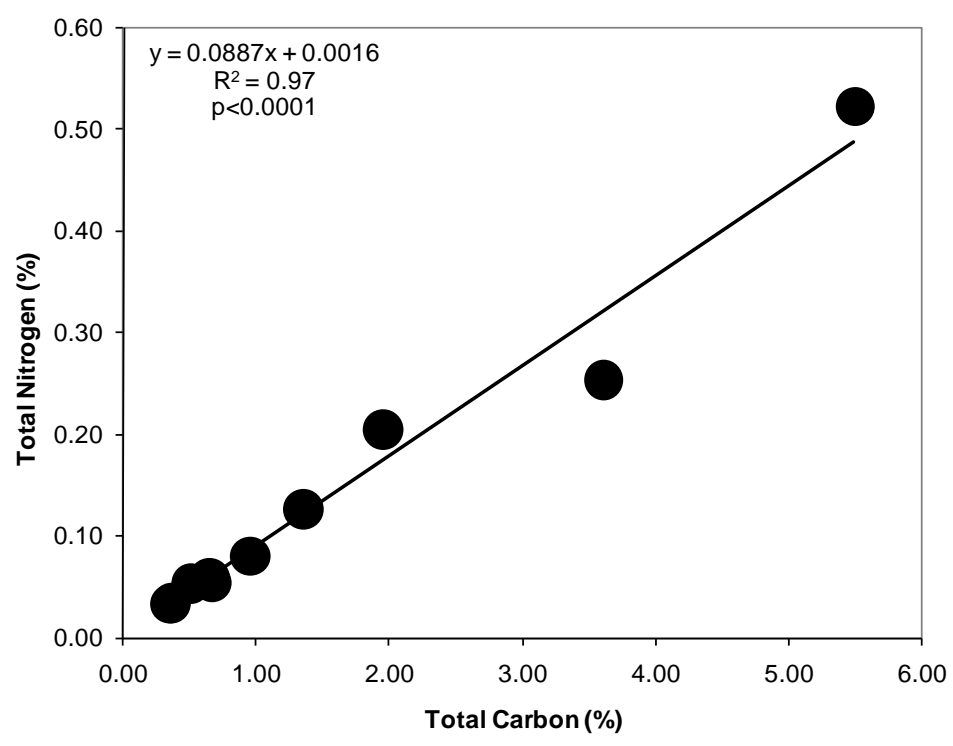

Figure 7. Relationship between total nitrogen and total carbon in Gosaikunda lake within Langtang National Park in central Nepal. 


\section{Discussion}

There was snow fall during the time of sampling and hence the average air temperature was $-0.05^{\circ} \mathrm{C}$ but the water temperature had nearly $2.6^{\circ} \mathrm{C}$ variation at different sampling sites with higher temperature at northern and western sites of the lake because of direct exposure of sunrays from noon to the evening. The measured low EC suggest the slow dissolution of minerals due to low temperature and lack of fresh reactive mineral surfaces. The $\mathrm{pH}$ appeared slightly alkaline along the southern lake shore possibly due to the presence of carbonate rocks. The higher suspended sediments at the outlet point and sites near the trail are probably related of human activities at these sites. Livestock may have some influence on chemical parameter at some sites. However dilution with clear inflowing water could also have determined the chemical composition. The water quality of Gosaikunda lake is very good despite this human impact.

\subsection{Spatial Variation in Chemical Compositions}

The concentrations of most of the measured chemical parameters were enhanced near the trail and temple as well as in the western part of the lake where temperature was slightly higher because of the landscape position. Dilution of dissolved and particulate matter in the eastern part of the lake as well as slightly lower temperatures could also be related to the inflow of colder water from the glaciers (inlet point between GKS5 and GKS6). Based on the abundance of chemical species carbonate and aluminosilicate dissolution coupled with sulfide oxidation appeared as the major geochemical processes regulating the distribution of chemical species within the Gosaikund lake. Such dominant geochemical processes were reported earlier within the Langtang basin in central Himalaya and other glacierized basins elsewhere in the world [5]-[8] [12] [35] [36]. Sulfate appeared to contribute highest concentration to the sum of anions suggesting pyrite dissolution as a major source of this ion, whereas alkalinity, mainly bicarbonate, controlled the anionic concentration of the supraglacial ponds and glacier meltwater within Lirung debris covered glacier in Langtang valley [5]-[8] and within supraglacial ponds and glacial melt water in Khumbhu glacier in Everest Himalaya region in North Eastern Nepal [13] [24]. In earlier studies the oxidation of pyrite in pyrite rich environment was characterized as follows [2] [37] [38]:

$$
\mathrm{FeS}_{2}+3.5 \mathrm{O}_{2}+\mathrm{H}_{2} \mathrm{O} \rightarrow \mathrm{Fe}^{2+}+2 \mathrm{SO}_{4}^{2-}+2 \mathrm{H}^{+}
$$

Differences in proton concentration among lake sites could be due to variations in oxidation of pyrite or variations in the presence of limestones or carbonate ions at different position of the lake which neutralizes acid production [37] [39]. The lower alkalinity was probably due to the intense oxidation of pyrite or used to neutralize acid ions. The alternative explanation may be less availability of limestones and slow dissolution of aluminosilicate minerals due to low temperature and low physical denudation rate within the region. The dominance of calcium within the lake suggests that calcite dissolution is a significant geochemical process which takes place as:

$$
\mathrm{CaCO}_{3}+\mathrm{CO}_{2}(\mathrm{aq})+\mathrm{H}_{2} \mathrm{O} \rightarrow \mathrm{Ca}^{2+}+2 \mathrm{HCO}_{3}^{-}
$$

Sodium is released from aluminosilicate minerals primarily from albite and the ion appeared as the second dominant base cations within the lake. The geochemical process of albite (Na-feldspar) weathering takes place as follows:

$$
2 \mathrm{NaAlSi}_{3} \mathrm{O}_{8}+2 \mathrm{CO}_{2}+3 \mathrm{H}_{2} \mathrm{O} \rightarrow \mathrm{Al}_{2} \mathrm{Si}_{2} \mathrm{O}_{5}(\mathrm{OH})_{4}+2 \mathrm{Na}^{+}+2 \mathrm{HCO}_{3}^{-}+4 \mathrm{SiO}_{2}
$$

The high concentration of ammonium detected at the outlet point and its surrounding area are probably due to human activities and livestock influence. The low concentration of nitrate and phosphate showed the oligotrophic character of the lake which is related to low input related to thin soil cover, little vegetation and slow chemical weathering at high altitudes. The high silicon concentration at sites close to the trails showed high physical erosion rates and enhanced silicate dissolution (Figure 4). The contribution of major solutes from sea-salt origin seems negligible to the total concentration of those ions except for sodium.

\subsection{Spatial Variation in DOC, TDN and DIC Species}

The average DOC was $1.8 \mathrm{mg} \cdot \mathrm{L}^{-1}$ and confirms that the lake is oligotrophic [40]. The DOC concentrations are in the range of those along the Langtang Narayani river system in central Nepal Himalaya except for few places 
which have enhanced values due to input from forested landscape, they are about three times less than the DOC concentration in the Taudaha pond within Kathmandu valley and ten times less than the heavily urbanized Bagmati river system within Kathmandu valley [41]-[44]. The low DOC content is probably due to the absence of vegetation and a relatively pristine area. The slightly higher DOC concentrations at sites GKS 6, GKS 7, GKS 9 and GKS 10 are due to the human and livestock influence. The TDN concentration of the Gosaikunda lake is nearly three times less than in the Taudaha pond within Kathmandu valley and more than twenty times less than in the heavily urbanized Bagmati river system within Kathmandu valley which is probably due to the difference in human impacts [12]. The variation pattern of TDN appeared quite similar to that of DOC suggesting that the same factors are responsible for their variations. The dissolved carbonic species appeared much lower than in the Taudaha pond where the partial pressure of carbon dioxide $\left(\mathrm{pCO}_{2}\right)$ revealed super saturation [43]. All inorganic carbon species showed increasing concentration from GKS 1 to GKS 10 except for carbonate $\left(\mathrm{CO}_{3}\right)$. Such decrease in concentration of carbonate is directly linked with the neutralization processes of the acid products by the alkaline limestones [38] [40]. The authors observed clear trend of increase in partial pressure of carbon dioxide $\left(\mathrm{pCO}_{2}\right)$ with decrease in carbonate within the Gosikunda lake (Figure 6(c)). Hence the pyrite oxidation acidity neutralized by the presence of carbonate ions within the lake which takes place as follows:

$$
\mathrm{H}_{2} \mathrm{SO}_{4}+\mathrm{CO}_{3}^{2-} \rightarrow \mathrm{H}_{2} \mathrm{O}+\mathrm{CO}_{2} \uparrow+\mathrm{SO}_{4}^{2-}
$$

The contribution of bicarbonate to total dissolved inorganic carbon content was much higher than the other inorganic carbon species probably due to dissolution of minerals which produces bicarbonate as a major product (Figure 6(a)). The partial pressure of carbon dioxide $\left(\mathrm{pCO}_{2}\right)$ revealed under saturation probably due to less respiration and lower decomposition rate due to less amounts of organic matter and lower temperature. The $\mathrm{pCO}_{2}$ of Gosaikunda lake is much lower than the Taudaha pond and heavily urbanized Bagmati river system within Kathmandu valley [43] [44], lower than the lowland rivers in UK [45] [46] and several folds lower than the tropical landscape in Puerto Rico [31]. The spatial variations in proton, major solutes, dissolved inorganic carbon species including $\mathrm{pCO}_{2}$, DOC and TDN within the Gosaikunda lake are due to the spatial variation in pyrite minerals which fueled the dissolution process, spatial variability of availability of fresh reactive mineral surfaces, variation in organic matter contents due to specific site conditions and human and livestock influence. The acid neutrality is primarily controlled by the availability of alkaline materials like limestones and especially in the presence of carbonates. In other words, carbonate controls the concentration of $\mathrm{pCO}_{2}$ and hence controls the solute concentrations within the lake.

\subsection{Composition of Surface Sediments of Lake}

The average concentration of POC in lake sediment is quite low (1.6\%) in Gosaikunda lake with similar results reported in sediments of either oligotrophic conditions or high dilution of organic matter by mineral matter [47]. The average $\mathrm{C} / \mathrm{N}$ ratio of the surface sediment of Gosaikunda lake shows a mixed origin of aquatic matter and land plants (Table 5). Meyers [48] documented that the $\mathrm{C} / \mathrm{N}$ ratios of aquatic organic matter ranges from 4 to 10 and the $\mathrm{C} / \mathrm{N}$ ratios appeared 20 or higher in terrestrial vascular plant materials. $\delta^{13} \mathrm{C}$ values of $\mathrm{C}_{3}$-plants are normally between $-30 \%$ and $-22 \%$ whereas $\mathrm{C}_{4}$-plants have $\delta^{13} \mathrm{C}-15 \%$ and $-8 \%$ [ [49] [50]. Gosaikunda lake is at an altitude not much below $4500 \mathrm{~m}$ asl which is the altitude above which only $\mathrm{C}_{3}$-plants can grow [51] so that we can assume that $\mathrm{C}_{3}$-grasses are dominant land plants. Due to the lower partial pressure of $\mathrm{CO}_{2}$, fractionation during its uptake is less than at lower altitudes so that the $\delta^{13} \mathrm{C}$ values are in the higher range of $\mathrm{C}_{3}$-plants [52] [53]. The $\delta^{13} \mathrm{C}$ values in Gosaikunda lake confirm a mixed origin of $\mathrm{C}_{3}$-plants and aquatic organic matter as suggested by the $\mathrm{C} / \mathrm{N}$ ratios. $\delta^{15} \mathrm{~N}$ values in the sediments are low $(0.7 \%$ - $4.8 \%$ ) compared to low altitude lakes which have $\delta^{15} \mathrm{~N}$ values of $2 \%$ - 8\% [43] [54] [55]. The $\delta^{15} \mathrm{~N}$ of soils at high altitudes are, however, often between $0 \%$ and $4 \%$ which could be related with declining temperatures [56]. Moreover, it was observed that anthropogenic induced glacier melt supplies isotopically light nitrogen [57].

\section{Conclusion}

The regulating factors and geochemical processes of the Gosaikunda lake are evaluated in order to understand the water quality and ecological status of the lake within Langtang National Park in central Nepal. Most of the measured chemical parameters showed similar spatial variation patterns within the lake. Higher concentrations of major solutes appeared at the northern lake shore near the trail areas due to human and livestock influence 
and relatively higher temperature than the other sites. Despite this slight anthropogenic disturbance the lake is oligotrophic and largely pristine. The concentration of all inorganic carbon species appeared to increase from GKS 1 to GKS 10 except for carbonate. The partial pressure of carbon dioxide $\left(\mathrm{pCO}_{2}\right)$ and carbonate showed an opposite trend suggesting that conversion of $\mathrm{pCO}_{2}$ to carbonate during dissolution process. The sulfide oxidation coupled with carbonate and aluminosilicate dissolution appeared as the dominant geochemical processes which controls the chemistry of Gosaikunda lake. The spatial variability of available minerals, spatial variations in consumption of $\mathrm{pCO}_{2}$, variation in water depths, variation in water temperature and variation in impacts of humans and livestock collectively controls the chemistry of Gosaikunda lake. Unlike urban ponds, supraglacial ponds within Himalaya and other pristine and heavily urbanized river systems and streams, the $\mathrm{pCO}_{2}$ was under saturated within this lake which further suggests a slow dissolution processes within the landscape. Organic matter in the lake is of mixed aquatic and land plant origin with land plants being mostly $\mathrm{C}_{3}$-grasses, typical of such high altitudes, which can fractionate less due to the low $\mathrm{CO}_{2}$-partial pressure. Isotopically light nitrogen found in lake sediments could be derived from soils or from glacier melt.

\section{Acknowledgements}

The authors thank Tom Jäppinen and Lisette Kretzschmann for their help in the lab and Samjawal Bajracharya from ICIMOD for his help in preparing the watershed map. The authors thank Frauke Langenberg for her help to analyze stable $\mathrm{C}$ and $\mathrm{N}$ isotopes and Ronny Lauerwald for his help to run PhreeqC. Thanks to R Tamang, $\mathrm{R}$ Subedi, D Bhatt, G Pant and other members of the field campaign for their help and support during the sampling. This research work was supported through the Cluster of Excellence "CliSAP" (EXC177), KlimaCampus-University of Hamburg, funded through the German Science Foundation (DFG).

\section{References}

[1] Gibbs, R.J. (1970) Mechanisms Controlling World Water Chemistry. Science, 170, 1088-1090. http://dx.doi.org/10.1126/science.170.3962.1088

[2] Garrels, R.M. and Mackenzie, F.T. (1971) Evolution of Sedimentary Rocks. W. W. Norton and Company, Inc., New York, 397p.

[3] Stallard, R.F. and Edmond, J.M. (1983) Geochemistry of the Amazon: 2. The Influence of Geology and Weathering Environment on the Dissolved Load. Journal of Geophysical Research: Oceans, 88, 9671-9688. http://dx.doi.org/10.1029/JC088iC14p09671

[4] Hartmann, J. (2009) Bicarbonate Fluxes and $\mathrm{CO}_{2}$ Consumption by Chemical Weathering on the Japanese Archipelago: Application of Multi-Lithological Model Framework. Chemical Geology, 265, 237-271. http://dx.doi.org/10.1016/j.chemgeo.2009.03.024

[5] Bhatt, M.P., Masuzawa, T., Yamamoto, M., Sakai, A. and Fujita, K. (2000) Seasonal Changes in Dissolved Chemical Composition and Flux of Melt Water Draining from Lirung Glacier in the Nepal Himalayas. Proceedings of a Workshop on Debris-Coved Glaciers held at Seattle, IAHS Publ. No. 264, Washington, 277-288.

[6] Bhatt, M.P., Masuzawa, T., Yamamoto, M. and Takeuchi, N. (2007) Chemical Characteristics of Pond Waters within the Debris Area of Lirung Glacier in Nepal Himalaya. Journal of Limnology, 66, 71-80. http://dx.doi.org/10.4081/jlimnol.2007.71

[7] Bhatt, M.P., Masuzawa, T., Yamamoto, M. and McDowell, W.H. (2008) Chemical Weathering in Central Himalaya: Dissolved Silica Dynamics in Glacier Meltwater. International Conference on Hydrology and Climate Change in Mountainous Area (ICHCC), SOHAM-UNESCO, Kathmandu, 162-179.

[8] Bhatt, M.P., Masuzawa, T., Yamamoto, M. and Gardner, K.H. (2009) Spatial Variations in Chemical Compositions along Langtang-Narayani River System in Central Nepal. Environmental Geology, 57, 557-569. http://dx.doi.org/10.1007/s00254-008-1325-X

[9] Bhatt, M.P. and Hartmann, J. (2012) Trends in Solute Fluxes across a 3.8 km Elevation Transaction from Narayani River System in Central Himalaya. In: Goldschmidt Conference, Mineralogical Society, Montreal.

[10] Collins, D.N. (1998) Suspended Sediment Flux in Meltwaters Draining from Batura Glacier as an Indicator of the Rate of Glacial Erosion in the Karakoram Mountain. Quaternary Proceedings, 6, 1-10, Owen, LA, Mountain Glaciations, Chichester, Wiley.

[11] France-Lanord, C., Evans, M., Hurtrez, J.E. and Riotte, J. (2003) Annual Dissolved Fluxes from Central Nepal Rivers: Budget of Chemical Erosion in the Himalayas. Comptes Rendus Geoscience, 335, 1131-1140. http://dx.doi.org/10.1016/j.crte.2003.09.014 
[12] Hasnain, S.I. and Thayyen, R.J. (1999) Controls on the Major Ion Chemistry of Dokriani Glacier Meltwaters, Ganga Basin, Narwhal Himalaya, India. Journal of Glaciology, 45, 87-92.

[13] Reynolds, B., Chapman, P.J., French, M.C., Jenkin, A. and Wheater, H.S. (1995) Major, Minor and Trace Element Chemistry of Surface Waters in the Everest Region of Nepal. In: Tonnessen, K.A., Williams, M.W. and Tranter, M., Eds., Biogeochemistry of Seasonally Snow-Covered Catchments, The International Association of Hydrological Sciences Publications, Boulder, Colorado, 405-412.

[14] Sarin, M.M., Krishnaswamy, S., Trivedi, J.R. and Sharma, K.K. (1992) Major Ion Chemistry of the Ganga Source Waters: Weathering in the High Altitude Himalaya. Proceedings of Indian Academy of Science (Earth Planet Science), 101, 89-98.

[15] Chakrapani, G.J. (2002) Water and Sediment Geochemistry of Major Kumaun Himalayan Lakes, India. Environmental Geology, 43, 99-107. http://dx.doi.org/10.1007/s00254-002-0613-0

[16] Das, B.K. and Dhiman, S.C. (2003) Water and Sediment Chemistry of Higher Himalayan Lakes in the Spiti Valley: Control on Weathering, Provenance and Tectonic Setting on the Basin. Environmental Geology, 44, 717-730. http://dx.doi.org/10.1007/s00254-003-0821-2

[17] Das, B.K., Gaye, B. and Malik, M.A. (2010) Biogeochemistry and Paleoclimate Variability during the Holocene: A Record from Mansar Lake, Lesser Himalaya. Environmental Earth Science, 61, 565-574. http://dx.doi.org/10.1007/s12665-009-0366-0

[18] Das, B.K., Gaye, B. and Kaur, B.P. (2008) Geochemistry of Renuka Lake and Wetland Sediment, Lesser Himalaya (India): Implications for Source-Area Weathering, Provenance and Tectonic Setting. Environmental Geology, 54, 147163. http://dx.doi.org/10.1007/s00254-007-0801-z

[19] Jones, J.R., Knowlton, M.F. and Swar, D.B. (1989) Limnological Reconnaissance of Waterbodies in Central and Southern Nepal. Hydrobiologia, 184, 171-189. http://dx.doi.org/10.1007/BF02392954

[20] Kamiyama, K. (1984) Lakes and Sediments around Yala Glacier. In: Higuchi, K., Ed., Glacier Studies in Langtang Valley, Data Center of Glacier Research, Water Research Institute, Nagoya University, Nagoya, 85-89.

[21] Lohman, K., Jones, J.R., Knowlton, M.F., Swar, D.B., Pamperl, M.A. and Brazos, B.J. (1988) Pre- and Post-Monsoon Limnological Characteristics of Lakes in the Pokhara and Kathmandu Valleys, Nepal. Verhandlungen des Internationalen Verein Limnologie, 23, 558-565.

[22] Takeuchi, N. and Kohshima, S. (2000) Effect of Debris Cover on Species Composition of Living Organism in Supraglacial Lakes on a Himalayan Glacier. Proceedings of a Workshop on Debris Covered Glaciers, Seattle, 13-15 September 2000, 267-275.

[23] Takeuchi, N., Sakai, A., Kohshima, S., Fujita, K. and Nakawo, M. (2012) Variation in Suspended Sediment Concentration of Supraglacial Lakes on Debris Covered Area of the Lirung Glacier in the Nepal Himalayas. Aires Global Environmental Research, 16, 95-104.

[24] Tartai, G.A., Tartari, G. and Mosello, R. (1998) Water Chemistry of High Altitude Lakes in the Khumbu and Imja Khola Valleys (Nepalese Himalayas). Memorie dell' Istituto Italiano di Idrobiologia, 57, 51-76.

[25] Bhandari, B.B. (2009) Wise Use of Wetlands in Nepal. Banko Jankari Special Issue, IUCN, Kathmandu, 10-17.

[26] Inger, S. and Harris, B.W. (1992) Tectonothermal Evolution of the High Himalayan Crystalline Sequence, Langtang Valley, Northern Nepal. Journal of Metamorphic Geology, 10, 439-452.

http://dx.doi.org/10.1111/j.1525-1314.1992.tb00095.x

[27] DMG (1980) Geological Map of Central Nepal. Department of Mines and Geology, Kathmandu.

[28] DMG (1994) Geological Map of Nepal. Department of Mines and Geology, Kathmandu.

[29] SD (1984) Land System Map, Central Development Region, Nepal. Survey Department, Kathmandu.

[30] APHA (1995) Standard Method for the Examination of Water and Waste Water. 19th Edition, American Public Health Association, Washington DC.

[31] Bhatt, M.P. and McDowell, W.H. (2007) Controls on Major Solutes within the Drainage Network of a Rapidly Weathering Tropical Watershed. Water Resources Research, 43, Published Online. http://dx.doi.org/10.1029/2007WR005915

[32] Keene, W.C., Pszenny, A.A.P., Galloway, J.N. and Hawley, M.E. (1986) Sea-Salt Corrections and Interpretation of Constituent Ratios in Marine Precipitation. Journal of Geophysical Research, 91, 6647-6658. http://dx.doi.org/10.1029/JD091iD06p06647

[33] Millot, R., Gaillardet, J., Dupre, B. and Allegre, C.J. (2002) The Global Control of Silicate Weathering Rates and the Coupling with Physical Erosion: New Insights from Rivers of the Canadian Shield. Earth and Planetary Science Letters, 196, 83-98. http://dx.doi.org/10.1016/S0012-821X(01)00599-4 
[34] McDowell, W.H., Sanchez, C.G., Asbury, C.E. and Ramos Pérez, C.R. (1990) Influence of Sea Salt Aerosols and Long Range Transport on Precipitation Chemistry at El Verde, Puerto Rico. Atmospheric Environment, 24, 2813-2821. http://dx.doi.org/10.1016/0960-1686(90)90168-M

[35] Tranter, M. and Raiswell, R. (1991) The Composition of the Englacial and Subglacial Component in Bulk Meltwaters Draining the Gornergletscher, Switzerland. Journal of Glaciology, 37, 59-66.

[36] Tranter, M., Brown, G., Raiswell, R., Sharp, M. and Gurnell, A. (1993) A Conceptual Model of Solute Acquisition by Alpine Glacier Meltwaters. Journal of Glaciology, 39, 573-581.

[37] Descostes, M., Beaucaire, C., Mercier, F., Savoye, S., Joachim, S. and Pierpaolo, Z. (2002) Effects of Carbonate Ions on Pyrite (FeS2) Dissolution. Bulletin de la Societe Geologique de France, 173, 265-270. http://dx.doi.org/10.2113/173.3.265

[38] Drever, J.I. (1988) The Geochemistry of Natural Waters. 2nd Edition, Prentice Hall, Englewood Cliffs, 473.

[39] Evangelou, V.P.B. (1995) Pyrite Oxidation and Its Control. CRC Press, Florida, 295.

[40] Frimmel, F.H. and Abbt-Braun, G. (2009) Dissolved Organic Matter (DOM) in Natural Environments. In: Sensei, N., Xing, B.P.K., Huang, P.M., Eds., Biophysico-Chemical Processes Involving Natural Nonliving Organic Matter in Environmental Systems, John Wiley and Sons, Hoboken, 367-406. http://dx.doi.org/10.1002/9780470494950.ch10

[41] Bhatt, M.P. and Gardner, K.H. (2009) Variation in DOC and Trace Metal Concentration along the Heavily Urbanized Basin in Kathmandu Valley, Nepal. Environmental Geology, 58, 867-876. http://dx.doi.org/10.1007/s00254-008-1562-z

[42] Bhatt, M.P. and McDowell, W.H. (2007) Evolution of Chemistry along the Bagmati Drainage Network in Kathmandu Valley. Water, Air, Soil Pollution, 185, 165-176. http://dx.doi.org/10.1007/s11270-007-9439-4

[43] Bhatt, M.P., Bhatt, S. and Gaye, B. (2013) Controls on Pond Water Chemistry within Kathmandu Valley, Nepal. International Journal of Lakes and Rivers, 6, 153-172.

[44] Bhatt, M.P., McDowell, W.H., Gardner, K.H. and Hartmann, J. (2014) Chemistry of the Heavily Urbanized Bagmati River System in Kathmandu Valley, Nepal: Export of Organic Matter, Nutrients, Major Ions, Silica and Metals. Environmental Earth Sciences, 71, 911-922.

[45] Bowes, M.J., Smith, J.T., Neal, C., Leach, D.V., Scarlett, P.M., Wickham, H.D., Harman, S.A., Armstrong, L.K., Davy-Bowker, J., Haft, M. and Davies, C.E. (2011) Changes in Water Quality of the River Frome (UK) from 1965 to 2009: Is Phosphorus Mitigation Finally Working? Science of the Total Environment, 409, 3418-3430.

[46] Neal, C., House, W.A., Jarvie, H.P. and Eatherall, A. (1998) The Significance of Dissolved Carbon Dioxide in Major Lowland Rivers Entering the North Sea. Science of the Total Environment, 210-211, 187-203.

[47] Meyers, P.A. (2003) Applications of Organic Geochemistry to Paleolimnological Reconstructions: A Summary of Examples from the Laurentian Great Lakes. Organic Geochemistry, 34, 261-289. http://dx.doi.org/10.1016/S0146-6380(02)00168-7

[48] Meyers, P.A. (1994) Preservation of Elemental and Isotopic Source Identification of Sedimentary Organic Matter. Chemical Geology, 114, 289-302. http://dx.doi.org/10.1016/0009-2541(94)90059-0

[49] Smith, B. and Epstein, S. (1971) Two Categories of ${ }^{13} \mathrm{C} /{ }^{12} \mathrm{C}$ Ratios for Higher Plants. Plant Physiology, 47, $380-384$. http://dx.doi.org/10.1104/pp.47.3.380

[50] Hatch, M.D. and Slack, C.R. (1970) Photosynthetic $\mathrm{CO}_{2}$-Fixation Pathways. Annual Review of Plant Physiology, 2, 141-162. http://dx.doi.org/10.1146/annurev.pp.21.060170.001041

[51] Tieszen, L.L., Senyimba, M.M., Imbamba, S.K. and Troughton, J.H. (1979) The Distribution of $C_{3}$ and $C_{4}$ Grasses and Carbon Isotope Discrimination along an Altitude and Moisture Gradient in Kenya. Oceanologia, 37, 337-350.

[52] Körner, C., Farquhar, G.D. and Roksandic, Z. (1988) A Global Survey of Carbin Isotope Discrimination in Plants from High Altitude. Oceanologia, 74, 623-632.

[53] Körner, C., Farquhar, G.D. and Wang, S.C. (1991) Carbon Isotope Discrimination by Plants Follows Latitudinal and Altitudinal Trends. Oceanologia, 88, 30-40.

[54] Maksymowska, D., Richard, P., Piekarek-Jankowska, H. and Rivera, P. (2000) Chemical and Isotopic Composition of the Organic Matter Sources in the Golf of Gdansk (Southern Baltic Sea). Estuarine, Coastal and Shelf Science, 51, 585-598. http://dx.doi.org/10.1006/ecss.2000.0701

[55] Menzel, P., Gaye, B., Prasad, S., Stebich, M., Das, B.K., Anoop, A., Riedel, N. and Basavaiah, N. (2013) Influence of Bottom Water Anoxia on Nitrogen Isotopic Ratios and Amino Acid Contributions of Recent Sediments from Small Eutrophic Lonar Lake, Central India. Limnology and Oceanography, 58, 1061-1074.

[56] Amundson, R., Austin, A.T., Schuur, E.A.G., Yoo, K., Matzek, V., Kendall, C., Uebersax, A., Brenner, D. and Baisden, 
W.T. (2003) Global Patterns of the Isotopic Composition of Soil and Plant Nitrogen. Global Biogeochemical Cycles, 17, Published Online.

[57] Holtgrieve, G.W., Schindler, D.E., Leavitt, W.O., Ward, E.J., Bunting, L., Chen, G., Finley, B.P., Gregory-Eaves, I., Holmgren, S., Lisac, M.J., Lisi, P.J., Nydick, K., Rogers, L.A., Saros, J.E., Selbie, D.T., Shapley, M.D., Walsh, P.B. and Wolfe, A.P. (2011) A Coherent Signature of Anthropogenic Nitrogen Deposition to Remote Watersheds of the Northern Hemisphere. Science, 334, 1545-1548. 
Scientific Research Publishing (SCIRP) is one of the largest Open Access journal publishers. It is currently publishing more than 200 open access, online, peer-reviewed journals covering a wide range of academic disciplines. SCIRP serves the worldwide academic communities and contributes to the progress and application of science with its publication.

Other selected journals from SCIRP are listed as below. Submit your manuscript to us via either submit@scirp.org or Online Submission Portal.
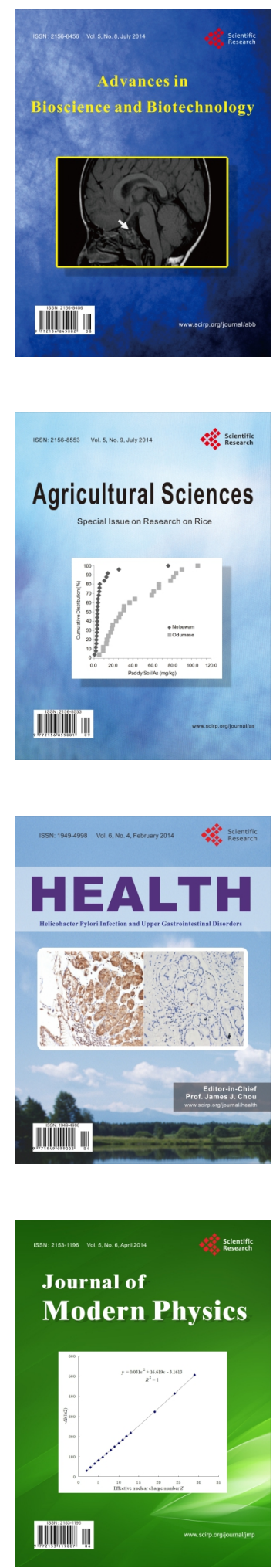
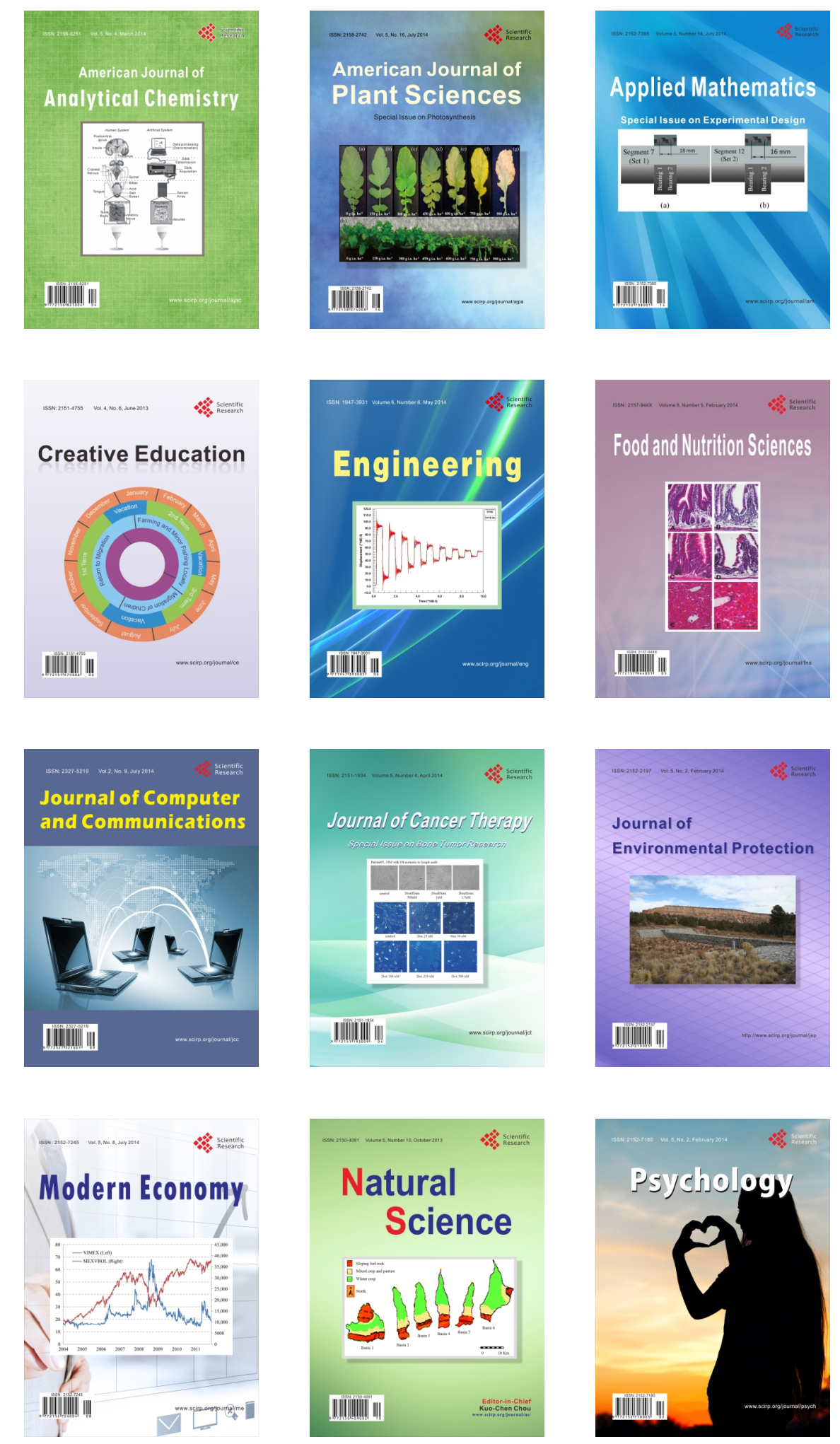